\title{
PENERAPAN METODE KOOPERATIF TAI DALAM MENENTUKAN KALIMAT UTAMA PADA PARAGRAF SISWA KELAS IV SD INPRES PABARUNG KECAMATAN TOMBOLO PAO KABUPATEN GOWA
}

\author{
Amir \\ SD Inpres Pabarung Tombolo Pao \\ Nip 196109251982061001 \\ amir@gmail.com
}

\begin{abstract}
Abstrak
Tujuan penelitian tindakan kelas ini adalah untuk mengetahui kemampuan siswa menentukan kalimat utama pada paragraf melalui penerapan metode kooperatif TAI diharapkan dapat meningkatkan proses dan hasil belajar bahasa Indonesia siswa kelas IV SD Inpres Pabarung Kecamatan Tombolo Pao. Teknik yang digunakan dalam penelitian ini adaah deskripsi kualitatif. Adapun rencana penelitian tindakan kelas ini dilaksanakan dalam dua siklus. Tiap siklus terdapat empat tahapan yaitu perencanaan, pelaksanaan, pengamatan, dan refleksi.

Hasil penelitian menunjukkan bahwa terdapat $0 \%$ siswa pada kategori sangat rendah, 6,67\% siswa pada kategori randah, 26,67\% pada kategori sedang, 50\% pada kategori tinggi dan 16,67\% pada kategori sangat tinggi. Skor rata-rata pada siklus I yaitu 69,83 pada kategori "sedang". Persentasi ketuntasan kelas sebesar $56,67 \%$. Sementara siklus II pada kategori rendah $0 \%$, siswa pada kategori sedang 3,33\% dan 30\% pada kategori tinggi serta 66,67\% siswa pada kategori sangat tinggi. Skor rata-rata dari hasil tes sebesar 82,17\% pada kategori "tinggi". Persentase ketuntasan kelas sebesar 93,33\% yaitu 28 dari 30 siswa, artinya hasil PTK ini dinyatakan meningkat secara signifikan.
\end{abstract}

Kata kunci: metode kooperatif TAI, menentukan kalimat utama, paragraph

\begin{abstract}
The purpose of this classroom action research is to know the ability of students to determine the main sentence in the paragraph through the application of cooperative methods TAI is expected to improve the process and results of learning Indonesian fourth graders Elementary School Pabarung District Tombolo Pao. The technique used in this research is a qualitative description. The class action research plan is implemented in two cycles. Each cycle has four stages: planning, implementation, observation, and reflection.

The results showed that there were 0\% of students in very low category, $6.67 \%$ of students in randah category, $26.67 \%$ in medium category, $50 \%$ in high category and $16.67 \%$ in very high category. The average score in cycle I was 69.83 in the "moderate" category. Graduation percentage percentage of $56.67 \%$. While the second cycle in the low category $0 \%$, students in the category of $3.33 \%$ and $30 \%$ in the high category and $66.67 \%$ of students in very high category. The average score of the test results was $82.17 \%$ in the "high" category. Percentage mastery of the class of $93.33 \%$ ie 28 out of 30 students, meaning the results of this PTK expressed significantly increased.
\end{abstract}

Keywords: TAI cooperative method, determine the main sentence, paragraph

\section{PENDAHULUAN}

Bahasa sebagai alat komunikasi mengandung beberapa sifat yakni, sistematik, mana-suka, ujar, manusiawi, 


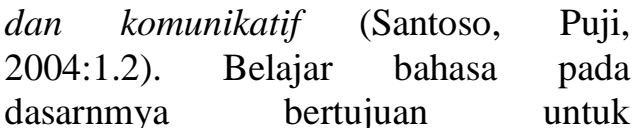
dasarnmya bertujuan untuk menggunakan bahasa untuk berbagai keperluan. Pembelajaran bahasa Indonesia merupakan salah satu pengetahuan yang mempunyai peranna penting dalam melatih berpikir siswa. Bahasa Indonesia berfungsi sebagai alat untuk mengembangkan ketajaman berpikir siswa yang dapat digunakan untuk memecahkan masalah yang dihadapi dalam kehidupannya secara logis dan sistematis. Untuk memahami pembelajaran bahasa yang komperhensif, guru hendaknya memilih pendekatan tidak sekedar berupa paparan yang bersifat hafalan dari bagian-bagian tertentu.

Pembelajaran tentang paragraf pada hakikatnya adalah pembelajaran keterampilan berbahasa yang lebih mengedepankan aspek kegiatan nyata, maka untuk mempelajari tentu tidaklah mudah apalagi pembelajaran adalah siswa tingkat Sekolah Dasar. Berdasarkan kenyataan siswa kelas IV SD Inpres Pabarung Kec. Tombolo Pao aktivitas dan kemampuan menentukan kalimat utama pada paragraf masih rendah. Dari jumlah 31 siswa yang mendapat nilai tuntas di atas KKM hanya 6 siswa $(19,35 \%)$ dan yang mendapat nilai belum tuntas ada 25 siswa $(80,65 \%)$ dengan nilai KKMnya 64. Nilai rata-rata ulangan harian 52,90. Rendahnya kemampuan menentukan kalimat utama dalam paragraf disebabkan karena siswa merasa bingung dan kesulitan dalam menentukan gagasan pokok, letak kalimat utama, kalimat penjelas, jenis paragraf, dalam menjawab pertanyaan/mengerjakan tugas diskusi kelompok tentang paragraf. Karena sistem pembelajaran yang masih terpusat pada guru (teacher center).

Harapan setelah penelitian tindakan kelas dengan melalui metode kooperatif siswa yang biasanya hanya pasif menerima pelajaran, berubah menjadi siswa yang aktif menentukan aktivitas dalam proses pembelajaran meningkat. Kemampuan siswa dalam menentukan kalimat utama pada paragraf juga meningkat yaitu memperoleh di atas KKM 64 dengan nilai rata-rata minimal 65.

\section{TINJAUAN PUSTAKA}

\section{a. Hakikat, Tujuan, Dan Tahapan Menulis}

1) Hakikat Menulis

Menulis yang dipandang sebagai kegiatan seseorang dalam menempatkan sesuatu pada sebuah dimensi ruang yang kosong adalah salah satu kemampuan seseorang dalam menggunakan bahasa tulis. Menulis itu berhubungan dengan membaca, berbicara, dan menyimak. Baik menulis maupun membaca, berbicara dan menyimak memiliki fungsi untuk manusia dalam mengomunikasikan pesan melalui bahasa. Syafi'ie (1988) berupa ide, kemauan, keinginan, perasaan maupun informasi. Jadi, tujuan utama dari pembelajaran menulis adalah untuk meningkatkan keterampilan siswa dalam mengkomunikasikan pesan melalui bahasa tulis. Pappas (1995) yaitu sebagai berikut: 1) Children (all human) are active, constructive learners. 2) Language is organized in different ways and in different patterns or registers, because it is used for different purposes in different social contexts. 3) Knowledge is organized and constructed by individual learners through social interaction.

2) Tujuan Menulis

Tujuan menulis adalah: 1) memberikan informasi; 2) meyakinkan atau mendesak; 3) menghibur atau menyenangkan; dan 4) mengekaspresikan perasaan dan emosi 
yang kuat. Hugo Hartig (dalam Tarigan 1986: 24-25) merumuskan tujuan menulis: 1) penugasan, sebenarnya tidak memilki tujuan karena orang yang menulis melakukannya karena tugas yang diberikan kepadanya; 2) altruistik, penulis bertujuan untuk menyenangkan pembaca, menghindarkan kedudukan pembaca,ingin menolong pembaca memahami, menghargai perasaan dan penalaranya, ingin membuat hidup para pembaca lebih mudah dan lebih menyenangkan dengan karyanya; 3) persuasif bertujuan meyakinkan para pembaca akan kebenaran gagasan yang diutarakannya; 4) informasional penulis bertujuan memberi informasi atau keterangan kepada para pembaca; 5) pernyataan diri penulis bertujuan memperkenalkan atau menyatakan dirinya kepada pembaca; 6) kreatif penulis bertujuan melibatkan dirinya dengan keinginan mencapai norma artistik, nilai-nilai kesenian; dan 7) pemecahan masalah penulis bertujuan untuk memecahkan masalah yang dihadapi.

\section{3) Tahapan Menulis}

Keterampilan menulis sebagai suatu proses pada dasarnya dapat melalui beberapa tahapan, yaitu merencanakan, menulis konsep, dan memperbaiki konsep. Merencanakan tulisan mencakup penentuan topik yang akan dibahas, penentuan tujuan tulisan, membuat garis-garis besar yang akan ditulis, dan pengumpulan data.

Penulisan konsep mencakup masalah pengembangan topik menjadi paragraf yang baik kemudian melakukan perbaikan konsep yang salah (Cahyani, 2002:129). Resmini (2002) mengemukakan bahwa menulis dapat dilakukan melalui beberapa tahapan, yaitu prewriting, drafting, revising, editing, dan publishing. Pada tahap prewriting, siswa berusaha mengemukakan apa yang akan mereka tulis, memilih tema, dan menentukan topik tulisan melalui kegiatan penjajagan ide atau dapat juga melalui observasi dan membaca buku. Pada tahap drafting, dilakukan pemberian chart sebagai media untuk memudahkan siswa menuangkan idenya secara tidak ragu-ragu karena pada tahap selanjutnya teks akan disusun, diperbaiki, diubah, dan disusun ulang. Pada tahap revising siswa melihat kembali tulisannya untuk selanjutnya menambah, mengganti, atau menghilangkan sebagian ide berkaitan dengan penggarapan struktur cerita yang telah disusunnya.

Tahap editing merupakan tahap penyempurnaan tulisan cerita yang dilakukan sebelum publikasi. Pada tahap ini siswa menyusun kembali tulisan yang telah dibuatnya melalui pengerjaan chart sehingga menjadi sebuah karangan yang utuh. Pada saat yang sama siswa juga melakukan perbaikan yang berkaitan dengan ejaan. Pada tahap publishing, siswa mempublikasikan hasil tulisannya melalui kegiatan berbagi hasil tulisan (sharing). Kegiatan ini dapat dilakukan di antaranya melalui kegiatan penugasan siswa untuk membacakan hasil karangan di depan kelas.

\section{4) Pengertian Paragraf}

Paragraf adalah satu kesatuan pikiran, suatu kesatuan yang lebih tinggi atau lebih luas dari pada kalimat: paragraf merupakan kimpulan kalimat yang berkaitan dalam suatu rangkaian untuk membentuk sebuah gagasan, Berkaitan dengan paragraf Akhadiah, dkk. (dalam Agus Suryamiharja, 1996: 46), menjelaskan bahwa "dalam paragraf terkandung satu unit buah pikiran yang didukung oleh semua kalimat utama atau kalimat topik, kalimat penjelas sapai kalimat penutup".

\section{b. Karakteristik Pembelajaran Bahasa Indonesia Di SD}

Pembelajaran bahasa Indonesia diarahkan pada peningkatan kemampuan 
peserta didik dalam berkomunikasi yang baik dan benar, baik secara lisan maupun tulis, serta menumbuhkan apresiasi terhadap hasil karya kesastraan Indonesia. Bredekamp (1987:3) menyatakan bahwa anak berkembang pada semua aspek perkembangan, baik fisik, emosional, sosial, dan kognitif. Goodman dalam Akhadiah menyatakan bahwa: 1) belajar bahasa lebih mudah terjadi jika bahasa itu disajikan secara holistik nyata, bermakna, dan fungsional jika bahasa itu disajikan dalam konteks dan dipilih peserta didik untuk digunakan; 2) belajar bahasa adalah belajar bagaimana mengungkapkan maksud sesuai dengan konteks lingkungan orang tua, kerabat, dan kebudayaan terdapat interdependensi antara perkembangan kognitif dan perkembangan kemampuan bahasa yang meliputi pikiran bergantung kepada bahasa dan bahasa bergantung kepada pikiran (Akhadiah, 1994: 10-11). Sesuai dengan teori belajar, perkembangan kognitif serta perkembangan bahasa pada anak usia lima sampai dengan delapan tahun atau kelas awal SD mempunyai karakteristik sebagai berikut: (1) kemampuan kognitif dan bahasa anak usia tersebut telah memadai untuk belajar dalam situasi yang lebih formal, (2) anak-anak seusia itu masih memandang sesuatu lebih sebagai keseluruhan, (3) sesuatu lebih mudah mereka pahami jika diperoleh melalui interaksi social dengan mengalaminya secara nayata dalam situasi yang menyenangkan, (4) situasi yang akrab, dilandasi penghargaan, pengertian, dan kasih sayang, serta lingkungan belajar kondusif dan terencana sangat membantu proses belajar yang efektif (Akhadiah, 1994: 89). Senada dengan Goodman, Suriasumantri (1995: 257) menyatakan bahwa belajar bahasa akan lebih mudah jika pembelajaran bersifat holistik, realistik, relevan, bermakna, dan fungsional, serta tidak lepas dari konteks pembicaraan.

Pembelajaran Bahasa Indonesia mencakup aspek mendengarkan, berbicara, membaca, dan menulis. Keempat aspek tersebut sebaiknya mendapat porsi yang seimbang. Dalam pelaksanaanya sebaiknya dilaksanakan secara terpadu, misalnya:

- mendengarkan — menulis berdiskusi

- mendengarkan — bercakap-cakap - membaca

- bercakap-cakap — menulis membaca

- membaca - berdiskusi memerankan

- menulis — melaporkan membahas

\section{c. Tujuan Pembelajaran Bahasa Indonesia di SD/MI}

Tujuan pelajaran Bahasa Indonesia di SD/Madrasah Ibtidaiyah yaitu: 1) Berkomunikasi secara efektif dan efisien sesuai dengan etika yang berlaku, baik secara lisan maupun tulis, 2) Menghargai penggunaan bahasa Indonesia sebagai bahasa persatuan dan bahasa negara, 3) Memahami bahasa Indonesia dan menggunakannya dengan tepat dan kreatif untuk berbagai tujuan, 4) Menggunakan bahasa untuk meningkatkan kemampuan intelektual, serta kematangan emosional dan sosial, 5) Menikmati dan memanfaatkan karya sastra untuk memperluas wawasan, memperhalus budi pekerti, serta meningkatkan pengetahuan dan kemampuan berbahasa, 6) Menghargai dan membanggakan sastra Indonesia sebagai khazanah budaya dan intelektual manusia Indonesia.

\section{d. Kemampuan Menentukan Kalimat Utama Paragraf}

1) Hakikat Kemampuan menemukan kalimat utama 
$\begin{array}{lrr}\begin{array}{l}\text { Menurut } \\ \text { kemampuan } \\ \text { kecakapan, }\end{array} & \begin{array}{c}\text { Chaplin } \\ \text { diartikan } \\ \text { ketangkasan, }\end{array} & \begin{array}{r}(2000: 1), \\ \text { sebagai } \\ \text { bakat, }\end{array}\end{array}$ kesanggupan; tenaga (daya kekuatan) untuk melakuakn sesuatu perbuatan. Kemampuan berarti semua kondisi psikologi yang diperlukan untuk menunjukan suatu aktivitas. Kalimat dalam paragraf yang mengungkapkan pikiran/gagasan utama disebut kalimat utama (kalimat topik), sedangkan kalimat-kalimat yang mengungkapkan pikiran penjelas disebut kalimat penjelas. Jadi, dalam sebuah paragraf hanya terdapat satu kalimat utama dan beberapa kalimat penjelas (Keraf, 1993: 76).

Nuriadi (2008: 144) menjelaskan kalimat utama yang juga disebut ide utama (main idea) adalah sebuah pernyataan yang dibuat penulis sebagai ungkapan (formulasi) umum terhadap topik. Unsur ini berperan sangat bahkan paling signifikan dalam sebuah paragraf. Setiap kalimat yang lain dalam paragraf tersebut harus mengacu atau berkait, baik langsung maupun tidak langsung pada pernyataan (ide pokok) ini.

Berdasarkan paparan tersebut, maka pada hakikatnya kemampuan menemukan kalimat utama pada paragraf adalah kesanggupan (kemahiran) siswa dalam menentukan/menemukan kalimat dalam paragraf yang mengungkapkan pikiran/gagasan utama disebut kalimat utama (kalimat topik).

\section{2) Hakikat Paragraf}

Paragraf merupakan inti penuangan buah pikiran dalam sebuah karangan. sebuah paragraf merupakan himpunan kalimat yang saling berkaitan dalam satu rangkaian untuk membentuk sebuah gagasan. Dalam paragraf terkandung satu unit buah pikiran yang didukung oleh semua kalimat dalam paragraf tersebut, mulai dari kalimat pengenal, kalimat utama atau kalimat topik, kalimat penjelas sampai kalimat penutup. Paragraf merupakan suatu bentuk pengungkapan gagasan berupa gubahan yang tercermin dalam rangkaian beberapa kalimat secara sistematis dan mencerminkan satu gagasan yang padu.

\section{e. Pembelajaran Kooperatif Tipe TAI (Team Assited Individualization atau Team Accelarated Instruction)}

Pembelajaran kooperatif tipe TAI ini dikembangkan oleh Slavin. Team Accelerated Instruction atau Team Assisted Individuallization memiliki persamaan dengan STAD dan TGT dalam penggunaan tim-tim pembelajaran empat anggota berkemampuan heterogen dan pemberian sertifikat untuk tim yang berkinerja tinggi. Bedanya bila STAD dan TGT menggunakan sebuah tatanan pengajaran tunggal untuk kelas, TAI menggabungkan pembelajaran kooperatif dengan pengajaran individual.

Team Assisted Individuallization memiliki dinamika motivasi sebanyak yang memiliki STAD dan TGT. Siswa terdorong dan saling membantu satu sama lain agar berhasil karena mereka ingin tim mereka berhasil. Tanggung jawab individual terjamin karena satusatunya skor yang diperhitungkan adalah skor tes final, dan siswa mengerjakan tes tersebut tanpa bantuan teman sesama tim. Siswa memiliki kesempatan yang sama untuk berhasil karena semua siswa telah ditempatkan sesuai dengan tingkat pengetahuan awal mereka.

Individualisasi yang merupakan bagian dari TAI tersebut membuat TAI jelas berbeda dari STAD dan TGT. Bila konsep-konsep sebelumnya tersebut belum dikuasai, konsep-konsep berikutnya akan sulit atau tidak mungkin dipelajari seorang siswa yang tidak dapat mengurangi atau mengalilkan akan gagal memahami pembagian panjang,seorang siswa yang tidak 
memahami konsep-konsep pecahan akan gagal untuk memahami apakah suatu desimal itu,dan seterusnya. Di dalam TAI, siswa bekerja pada kecepatan mereka sendiri, apabila mereka lemah dalam keterampilan-keterampilan prasyarat mereka, mereka terlebih dahulu dapat membangun sebuah landasan kuat berupa keterampilan prasyarat tersebut sebelum mereka belajar pokok bahasan lebih tinggi.

1) Komponen-komponen TAI

$$
\text { Model }
$$

kooperatif Team

pembelajaran Assisted Individualization memiliki delapan komponen sebagai berikut.

a) Teams, yaitu pembentukan kelompok heterogen yang terdiri atas 4 sampai 5 peserta didik,

b) Placement Test, yaitu pemberian pre-tes kepada peserta didik atau melihat rata-rata nilai harian peserta didik agar guru mengetahui kelemahan peserta didik pada bidang tertentu,

c) Student Creative, melaksanakan tugas dalam suatu kelompok dengan menciptakan situasi dimana keberhasilan individu ditentukan atau dipengaruhi oleh keberhasilan kelompoknya,

d) Team Study, yaitu tahapan tindakan belajar yang yang harus dilaksanakan oleh kelompok dan guru memberikan bantuan secara individual kepada peserta didik yang membutuhkan.

e) Team Scores and Team Recognition, yaitu pemberian skor terhadap hasil kerja kelompok dan memberikan kriteria penghargaan terhadap kelompok yang berhasil secara cemerlang dan kelompok yang dipandang kurang berhasil dalam menyelesaikan tugas,

f) Teaching Group, yakni pemberian materi secara singkat dari guru menjelang pemberian tugas kelompok, g) Fact Test, yaitu pelaksanaan tes-tes kecil berdasarkan fakta yang diperoleh peserta didik,

h) Whole-Class Units, yaitu pemberian materi oleh guru kembali diakhir waktu pembelajaran dengan strategi pemecahan masalah.

Unsur-unsur yang perlu diperhatikan dalam Team Assisted Individualization, Robert E. Slavin (dalam Kurniati 2007:25) adalah sebagai berikut.

a) Team (kelompok) Peserta didik dikelompokkan dalam kelompokkelompok yang terdiri dari 4 sampai 5 orang peserta didik dengan kemampuan yang berbeda.

b) Tes Penempatan Peserta didik diberi tes di awal pertemuan, kemudian peserta didik ditempatkan sesuai dengan nilai yang didapatkan dalam tes, sehingga didapatkan anggota yang heterogen (memiliki kemampuan berbeda) dalam kelompok.

c) Langkah-langkah Pembelajaran.

- Diawali dengan pengenalan konsep oleh guru dalam mengajar secara kelompok (diskusi singkat) dan memberikan langkah-langkah cara menyelesaikan masalah atau soal.

- Pemberian tes keterampilan yang terdiri dari 10 soal.

- Pemberian tes formatif yang terdiri dari dua paket soal, tes formatif $\mathrm{A}$ dan tes formatif $\mathrm{B}$, masing-masing terdiri dari 8 soal.

- Pemberian tes keseluruhan yang terdiri dari 10 soal.

- Pembahasan untuk tes keterampilan, tes formatif, dan tes keseluruhan.

a)

2) Langkah-langkah Pembelajaran TAI

a) Guru memberikan tugas kepada siswa untuk mempelajari materi 
pembelajaran secara individual yang sudah dipersiapkan oleh guru.

b) Guru memberikan kuis secara individual kepada siswa untuk mendapatkan skor dasar atau skor awal.

c) Guru membentuk beberapa kelompok. Setiap kelompok terdiri dari 4-5 siswa dengan kemampuan yan $\mathrm{g}$ berbeda-beda baik tingkat kemampuan (tinggi, sedang dan rendah) Jika mungkin anggota kelompok berasal dari ras, budaya, suku yang berbeda serta kesetaraan jender.

d) Hasil belajar siswa secara individual didiskusikan dalam kelompok. Dalam diskusi kelompok, setiap anggota kelompok saling memeriksa jawaban teman satu kelompok.

e) Guru memfasilitasi siswa dala m membuat rangkuman, mengarahkan, dan memberikan penegasan pada materi pembelajaran yang telah dipelajari.

f) Guru memberikan kuis kepada siswa secara individual.

g) Guru memberi penghargaan pada kelompok berdasarkan perolehan nilai peningkatan hasil belajar individual dari skor dasar ke skor kuis berikutnya.

\section{METODE PENELITIAN}

Proses penelitian tindakan kelas ini direncanakan berlangsung dalam dua siklus. Tiap siklus terdiri atas empat tahap, yaitu 1) perencanaan, 2) tindakan, 3) observasi, dan 4) refleksi. Permasalah-permasalahan yang muncul pada siklus I merupakan permasalahan yang harus dipecahkan pada siklus II.

1. Proses Pelaksanaan Siklus I

a. Perencanaan.
Pada tahap ini peneliti melakukan kegiatan: 1) Menyusun rencana pembelajaran sesuai dengan tindakan yang akan dilaksanakan. 2) Membuat perangkat pembelajaran. 3) Menyusun instrument penelitian yang akan digunakan, yaitu pedoman tes perbuatan, pedoman pengamatan, wawancara, jurnal, dokumentasi foto. Mempersiapkan model serta media yang akan digunakan, dan 5) Mempersiapkan materi yang akan diajarkan.

b. Tindakan.

Pada tahap ini dilakukan tindakan sesuai yang telah disusun dalam rencana pembelajaran. Materi pembelajarannya menentukan kalimat utama pada paragraf. Pada tahap awal pembelajaran siswa diberikan apersepsi untuk mengungkapkan pengetahuan siswa mengenai kegiatan diskusi. Guru meminta siswa untuk membentuk kelompok kecil yang beranggotakan 4 orang. Dengan teman sekelompok, siswa diminta mendiskusikan hal-hal yang ditemukannya dari model diskusi tersebut.

c. Observasi atau pengamatan.

Observasi dilakukan oleh peneliti pada saat belajar mengajarn berlangsung. Selain menyampaikan materi pembelajaran dan melakukan tes perbuatan, peneliti juga mengamati perilaku siswa selama proses pembelajaran.

\section{d. Refleksi}

Setelah proses tindakan siklus I berakhir, peneliti melakukan analisi mengenai hasil tes perbuatan, observasi, wawancara, jurnal, dokumentasi, foto. Hasil analisis tersebut digunakan untuk mengetahui seberapa besar keterampilan siswa, bagaimana sikap siswa selama mengikuti 
pembelajaran, dan kendala apa yang ditemui guru dan siswa dalam kegaiatan pembelajaran tersebut.

2. Proses Pelaksanaan Sikulus II

a. Perencanaan

Perencanan yang dilakukan adalah memperbaiki perencanaan yang telah dilakukan pada siklus I, pada tahap ini adalah sebagai berikut: 1) Memperbaiki rencana pembelajaran. 2) Mempersiapkan model yang akan digunakan. 3) Menyusun instrumen penelitian yang digunakan, yaitu pedoman tes perbuatan, pedoman pengamatan, pedoman wawancara, jurnal, dan sosiometri (lembar observasi siswa)

b. Tindakan

Tindakan yang dilakukan pada siklus ini adalah: 1) Guru mengadakan apersepsi untuk menggali pengetahuan siswa mengenai diskusi dengan menampilkan kembali materi yang telah diberikan. 2) Setelah penyajian materi selesai, guru memberikan kesempatan kepada siswa untuk bertanya atau mengajukan pendapat. 3) Guru meminta siswa untuk membentuk kelompok kembali dengan cara menentukan sepuluh siswa yang memiliki keterampilan berbicara yang baik pada siklus I. 4) Guru kembali menyiapkan model diskusi, siswa yang lain diminta untuk memperhatikan dengan baik. 5) Setelah semua tugas dikumpulkan, guru mengundi kelompok untuk tampil menyajikan hasil kerjanya di depan kelas dan siswa/kelompok lain boleh menanggapi

c. Observasi atau pengamatan.

Observasi dilakukan oleh peneliti pada saat kegiatan belajar mengajar berlangsung. Observasi ini digunakan untuk mengetahui adanya perubahan sikap siswa dalam mengikuti pembelajaran pada siklus II ini.

d. Refleksi

Akhir tindakan siklus II ini dilakukan analisis hasil tes perbuatan, observasi/pengamatan, wawancara, jurnal, dan sosiometri (lembar observasi siswa). Hasil analisis tersebut digunakan untuk mengetahui kendala-kendala apa yang dijumpai guru pada siklus II, bagaimana perubahan sikap siswa dalam mengikuti pembelajaran.

\section{HASIL PENELITIAN DAN PEMBAHASAN}

\section{a. Deskripsi Hasil Penelitian}

1) Analisis Kuantitatif

a) Deskripsi Hasil Tes Siklus I

Pada siklus I dilaksanakan tes hasil belajar siswa yang berbentuk ulangan harian. Adapaun analisis deskriptif skor perolehan siswa setelah diterapkan model pembelajaran Kooperatif tipe Team Assisted Individualization (TAI) pada siklus I seperti pada table berikut ini:

Statistik Skor Hasil Tes Siswa Pada Siklus I

\begin{tabular}{|c|c|}
\hline Statistik & Nilai Statistik \\
\hline Subyek & 30 \\
\hline Skor Ideal & 100 \\
\hline Skor Maksimum & 90 \\
\hline Skor Minimum & 50 \\
\hline Rentang Skor & 40 \\
\hline Skor Rata-Rata & 69,83 \\
\hline
\end{tabular}


Setelah skor hasil tes siswa diatas dikelompokkan kedalam lima kategori, maka diperoleh distribusi frekuensi dan persentase sebagai berikut:

Distribusi Frekuensi dan Persentase Skor Hasil Tes pada Siklus I

\begin{tabular}{|c|c|c|c|}
\hline Interval Skor & Kategori & Frekuensi & Persentase (\%) \\
\hline $0-54$ & Sangat Rendah & 0 & 0 \\
\hline $55-64$ & Rendah & 2 & 6,67 \\
\hline $65-79$ & Sedang & 8 & 26,67 \\
\hline $80-89$ & Tinggi & 15 & 50 \\
\hline $90-100$ & Sangat Tinggi & 5 & 16,67 \\
\hline \multicolumn{2}{|c|}{ Jumlah } & 30 & $100 \%$ \\
\hline
\end{tabular}

Dari tabel menunjukkan bahwa terdapat $0 \%$ siswa berada pada kategori sangat rendah, $6,67 \%$ siswa berada pada kategori randah, 26,67\% berada pada kategori sedang, $50 \%$ berada pada kategori tinggi dan $16,67 \%$ berada pada kategori sangat tinggi. Ini menunjukkan bahwa tingkat kemampuan siswa kelas IV SD Inpres Pabarung Kec. Tombolo Pao setelah dilakukan pembelajaran dengan diterapkan model pembelajaran Kooperatif tipe Team Assisted Individualization (TAI) berada pada kategori sedang. Disamping itu, sesuai skor rata-rata dari hasil tes pada siklus I yaitu 69,83 jika dikonversikan ke dalam skala kategori standar berada pada kategori "sedang". Hal ini berarti prestasi hasil belajar siswa kelas IV SD setelah menggunakan model pembelajaran Kooperatif tipe Team Assisted Individualization (TAI), berada dalam kategori "sedang".

Apabila hasil belajar siswa pada siklus I dianalisis, maka persentase ketuntasan belajar siswa pada siklus I dapat dilihat pada tabel berikut: Deskripsi Ketuntasan Belajar Kelas IV SD Inpres Pabarung Kec. Tombolo Pao

\begin{tabular}{|c|c|c|c|}
\hline $\begin{array}{c}\text { Sko } \\
\text { r }\end{array}$ & $\begin{array}{c}\text { Katego } \\
\text { ri }\end{array}$ & $\begin{array}{c}\text { Frekuen } \\
\text { si }\end{array}$ & $\begin{array}{c}\text { Persenta } \\
\text { se }(\%)\end{array}$ \\
\hline $\begin{array}{c}0- \\
64\end{array}$ & $\begin{array}{c}\text { Tidak } \\
\text { tuntas }\end{array}$ & 13 & 43,33 \\
\hline $\begin{array}{c}65- \\
100\end{array}$ & Tuntas & 17 & 56,67 \\
\hline \multicolumn{2}{|c|}{ Jumlah } & 30 & 100 \\
\hline
\end{tabular}

Dari tabel menunjukkan bahwa persentasi ketuntasan kelas sebesar $43,33 \%$ yaitu 13 siswa dari 30 siswa termasuk dalam kategori tidak tuntas dan 17 atau $56,67 \%$ siswa termasuk dalam kategori tuntas. Hal ini berarti bahwa masih ada siswa yang perlu perbaikan pada siklus berikutnya.

Berdasarkan kriteria hasil belajar mengenai ketuntasan kelas, yaitu $\geq 85 \%$, data hasil penelitian pada siklus I di atas dianggap belum tuntas kelas karena yang tuntas hanya mencapai $56,67 \%$ dari 30 siswa.

b) Deskripsi Hasil Tes Siklus II

Analisis terhadap skor hasil belajar siswa setelah diterapkan pembelajaran dengan menggunakan model pembelajaran Kooperatif tipe Team Assisted Individualization (TAI) selama berlangsungnya siklus II dapat dilihat pada tabel berikut:

Statistik Skor Hasil Tes Siswa Pada Siklus II

\begin{tabular}{|c|c|}
\hline Statistik & Nilai Statistik \\
\hline Subyek & 30 \\
\hline Skor Ideal & 100 \\
\hline Skor Maksimum & 100 \\
\hline Skor Minimum & 60 \\
\hline Rentang Skor & 40 \\
\hline Skor Rata-Rata & 82,17 \\
\hline
\end{tabular}

Dari tabel menunjukkan bahwa skor rata-rata hasil belajar menentukan kalimat utama menggunakan model pembelajaran Kooperatif tipe Team 
Assisted Individualization (TAI) pada siswa kelas IV SD Inpres SD Inpres Pabarung Kec. Tombolo Pao adalah nilai rata-rata yang diperoleh yaitu 82,17 dari skor ideal yang mungkin dicapai adalah 100. Sedangkan secara individual skor yang dicapai siswa pada siklus II ini tersebar dengan skor terendah 60,00 dari skor tertinggi yang mungkin dicapai adalah 100, dengan rentang skor 40,00. Setelah skor hasil tes siswa dikelompokkan ke dalam skala kategori standar, maka diperoleh distribusi frekuensi dan persentase sebagai berikut:

Frekuensi dan Persentasi Skor Hasil Tes pada Siklus II

\begin{tabular}{|c|c|c|c|}
\hline Interval Skor & Kategori & Frekuensi & Persentase (\%) \\
\hline $0-54$ & Sangat Rendah & 0 & 0 \\
\hline $55-64$ & Rendah & 0 & 0 \\
\hline $65-79$ & Sedang & 1 & 3,33 \\
\hline $80-89$ & Tinggi & 9 & 30 \\
\hline $90-100$ & Sangat Tinggi & 20 & 66,67 \\
\hline \multicolumn{2}{|c|}{ Jumlah } & 30 & $100 \%$ \\
\hline
\end{tabular}

Dari tabel menunjukkan bahwa terdapat siswa berada pada kategori rendah $0 \%$, siswa berada pada kategori sedang 3,33\% dan $30 \%$ berada pada kategori tinggi serta $66,67 \%$ siswa berada pada kategori sangat tinggi. Hal ini menunjukkan bahwa tingkat kemampuan siswa kelas IV SD Inpres Pabarung Kec. Tombolo Pao setelah diterapkan model pembelajaran Kooperatif tipe Team Assisted Individualization (TAI) berada pada kategori tinggi. Di samping itu, sesuai skor rata-rata dari hasil tes pada siklus II yaitu sebesar $82,17 \%$, jika dikonversikan ke dalam skala kategori standar berada dalam kategori "tinggi". Hal ini berarti skor rata-rata prestasi hasil belajar siswa kelas IV SD Inpres Pabarung Kec. Tombolo Pao setelah diterapkan model pembelajaran Kooperatif tipe Team Assisted Individualization (TAI) berada dalam kategori "tinggi".

Dari hasil analisis deskriptif di atas menunjukkan bahwa hasil belajar Matematika siswa kelas kelas IV SD Inpres Pabarung Kec. Tombolo Pao setelah diterapkan model pembelajaran Kooperatif tipe Team Assisted Individualization (TAI) mengalami peningkatan. Hal ini dikatakan dengan melihat peningkatan hasi belajar dengan skor rata-rata yang diperoleh siswa dari 69,83 pada siklus I menjadi $82,17 \%$ pada siklus II. Apabila hasil belajar siswa pada siklus II dianalisis, maka persentase ketuntasan belajar pada siklus II dapat dilihat pada tabel berikut:

Deskripsi Ketuntasan Belajar Siswa Kelas kelas IV SD Inpres Pabarung

\begin{tabular}{|c|c|c|c|}
\hline Skor & Kategori & Frekuensi & $\begin{array}{c}\text { Persenta } \\
\text { se (\%) }\end{array}$ \\
\hline $\begin{array}{c}0- \\
64\end{array}$ & $\begin{array}{c}\text { Tidak } \\
\text { tuntas }\end{array}$ & 2 & 6,67 \\
\hline $\begin{array}{c}65- \\
100\end{array}$ & Tuntas & 28 & 93,33 \\
\hline \multicolumn{2}{|c|}{ Jumlah } & 30 & 100 \\
\hline
\end{tabular}

Dari tabel menunjukan bahwa persentase ketuntasan kelas sebesar 93,33\% yaitu 28 dari 30 siswa termasuk dalam kategori tuntas dan 6,67\% atau 2 dari 30 siswa termasuk dalam kategori tidak tuntas.

Berdasarkan kriteria hasil belajar mengenai ketuntasan kelas, yaitu $\geq 85 \%$, data hasil penelitian pada siklus II di atas dianggap tuntas kelas karena yang tuntas mencapai 93,33\% dari 30 siswa. 
2) Analisis Kualitatif

a) Siklus I
Pada siklus I, keaktifan siswa dapat dilihat pada lembar observasi yang ditunjukkan pada tabel berikut ini.

Keaktifan Siswa pada Siklus I

\begin{tabular}{|c|c|c|c|c|c|c|}
\hline \multirow{2}{*}{ No } & \multirow{2}{*}{ Komponen yang diamati } & \multicolumn{3}{|c|}{ Pertemuan } & \multirow{2}{*}{$\begin{array}{c}\text { Rata - } \\
\text { Rata }\end{array}$} & \multirow{2}{*}{$\%$} \\
\hline & & 1 & 2 & 3 & & \\
\hline 1 & $\begin{array}{l}\text { Siswa yang hadir pada saat } \\
\text { pembelajaran berlangsung. }\end{array}$ & 24 & 26 & 30 & 26,67 & 88,9 \\
\hline 2 & $\begin{array}{l}\text { Siswa yang mengerjakan dan } \\
\text { mengumpulkan PR. }\end{array}$ & 0 & 20 & 25 & 15 & 50 \\
\hline 3 & $\begin{array}{l}\text { Siswa yang melakukan aktivitas lain } \\
\text { pada saat pembelajaran berlangsung. }\end{array}$ & 7 & 5 & 3 & 5 & 16,67 \\
\hline 4 & $\begin{array}{l}\text { Siswa yang memperhatikan dan } \\
\text { mencatat pada saat pembelajaran } \\
\text { berlangsung. }\end{array}$ & 17 & 21 & 28 & 22 & 73,3 \\
\hline 5 & $\begin{array}{l}\text { Siswa yang bertanya tentang materi } \\
\text { pelajaran yang belum dimengerti. }\end{array}$ & 15 & 10 & 13 & 12,67 & 42,22 \\
\hline 6 & $\begin{array}{l}\text { Siswa yang mengajukan diri untuk } \\
\text { mengerjakan soal dipapan tulis. }\end{array}$ & 16 & 18 & 23 & 19 & 63,3 \\
\hline 7 & $\begin{array}{l}\text { Siswa yang tidak melengkapi alat yang } \\
\text { digunakan untuk membuat media. }\end{array}$ & 5 & 1 & 1 & 2,3 & 7,78 \\
\hline 8 & $\begin{array}{l}\text { Siswa yang bekerja sama dan } \\
\text { berpartisipasi dalam kelompok }\end{array}$ & 15 & 23 & 27 & 21,61 & 72,2 \\
\hline
\end{tabular}

Berdasarkan table di atas, dapat dilihat bahwa sekitar $88,9 \%$ siswa yang hadir pada Siklus I yang dilaksanakan sebanyak tiga kali pertemuan, sekitar $50 \%$ Siswa yang mengerjakan dan mengumpulkan PR, 16,67\% siswa Siswa yang melakukan aktivitas lain pada saat pembelajaran berlangsung, 73,3\% siswa yang memperhatikan dan mencatat pada saat pembelajaran, $42,2 \%$ siswa yang bertanya tentang materi yang belum dimengerti, $63,3 \%$ siswa yang mengajukan diri untuk mengerjakan soal di papan tulis, $7,78 \%$ siswa yang tidak melengkapi alat yang digunakan untuk membuat media, serta $72,2 \%$ siswa yang bekerja sama dan berpartisipasi dalam kelompok.

b) Siklus II

Pada Siklus II keaktifan siswa dapat dilihat pada tabel di bawah ini.

Keaktifan Siswa pada Siklus II

\begin{tabular}{|c|c|c|c|c|c|c|}
\hline \multirow{2}{*}{ No } & \multirow{2}{*}{ Komponen yang diamati } & \multicolumn{3}{|c|}{ Pertemuan } & \multirow{2}{*}{$\begin{array}{l}\text { Rata - } \\
\text { Rata }\end{array}$} & \multirow{2}{*}{$\%$} \\
\hline & & 1 & 2 & 3 & & \\
\hline 1 & $\begin{array}{l}\text { Siswa yang hadir pada saat } \\
\text { pembelajaran berlangsung. }\end{array}$ & 26 & 28 & 30 & 28 & 93,33 \\
\hline 2 & $\begin{array}{l}\text { Siswa yang mengerjakan dan } \\
\text { mengumpulkan PR. }\end{array}$ & 27 & 25 & 30 & 27,33 & 91,1 \\
\hline 3 & $\begin{array}{l}\text { Siswa yang melakukan aktivitas lain } \\
\text { pada saat pembelajaran berlangsung. }\end{array}$ & 4 & 3 & 2 & 3 & 10 \\
\hline 4 & $\begin{array}{l}\text { Siswa yang memperhatikan dan } \\
\text { mencatat pada saat pembelajaran } \\
\text { berlangsung. }\end{array}$ & 22 & 25 & 28 & 25 & 83,3 \\
\hline 5 & $\begin{array}{l}\text { Siswa yang bertanya tentang materi } \\
\text { pelajaran yang belum dimengerti. }\end{array}$ & 18 & 15 & 10 & 14,33 & 47,8 \\
\hline 6 & Siswa yang mengajukan diri untuk & 14 & 20 & 26 & 20 & 66,67 \\
\hline
\end{tabular}




\begin{tabular}{|c|l|c|c|c|c|c|}
\hline & mengerjakan soal dipapan tulis. & & & & & \\
\hline 7 & $\begin{array}{l}\text { Siswa yang tidak melengkapi alat yang } \\
\text { digunakan untuk membuat media. }\end{array}$ & 0 & 0 & 0 & 0 & 0 \\
\hline 8 & $\begin{array}{l}\text { Siswa yang bekerja sama dan } \\
\text { berpartisipasi dalam kelompok }\end{array}$ & 20 & 25 & 30 & 25 & 83,33 \\
\hline
\end{tabular}

Berdasarkan table di atas, dapat dilihat bahwa sekitar 93,33\% siswa yang hadir pada Siklus II yang dilaksanakan sebanyak empat kali pertemuan, sekitar 91,1\% Siswa yang mengerjakan dan mengumpulkan PR, $10 \%$ siswa Siswa yang melakukan aktivitas lain pada saat pembelajaran berlangsung, 78,3\% siswa yang memperhatikan dan mencatat pada saat pembelajaran, $47,8 \%$ siswa yang bertanya tentang materi yang belum dimengerti, $66,67 \%$ siswa yang mengajukan diri untuk mengerjakan soal dipapan tulis, 0\% siswa yang tidak melengkapi alat yang digunakan untuk membuat media, serta $83,33 \%$ siswa yang bekerja sama dan berpartisipasi dalam kelompok.

\section{3) Refleksi}

Dari analisis deskriptif kuantitatif dan kualitatif di atas dapat disimpulkan refleksi secara umum: 1) Hasil belajar siswa meningkat dari siklus I ke Siklus II yang dapat dilihat dari peningkatan nilai rata-rata dari siklus I ke siklus II. 2) Aktivitas siswa terhadap mata pelajaran menulis dapat dikatakan mengalami perubahan kearah yang lebih positif. Hal ini dapat terlihat dari lembar observasi aktivitas siswa yang meningkat dari siklus I ke siklus II. 3) Pandangan siswa terhadap penerapan model pembelajaran kooperatif tipe TAI sangat positif. Mereka menganggap bahwa metode pembelajaran tersebut memberikan peluang kepada mereka untuk lebih memahami materi, sedangkan ketua kelompok menjadi ajang untuk menimbulkan motifasi belajar pada dirinya untuk bersaing secara sehat. Selain itu metode pembelajaran ini menumbuhkan kekompakan antara anggota kelompok terutama pada saat mereka berdiskusi untuk mencari jawaban yang benar sehingga lebih berkesan dan mudah untuk diingat. 4) Tugas yang diberikan berfungsi untuk menguji kemampuan siswa dalam kerja kelompok. Hal ini menjadi pendorong yang akan menumbuhkan rasa kerja sama dalam menyelesaikan tugas kelompok yang diberikan oleh guru. 5) Pemberian pujian atau penghargaan kelompok yang berprestasi merupakan salah satu faktor yang mampu meningkatkan motivasi belajar setiap siswa.

\section{b. Pembahasan}

Hasil belajar menulis siswa kelas IV SD Inpres Pabarung Kec. Tombolo Pao Kabupaten Gowa melalui model pembelajaran Kooperatif tipe Team Assisted Individualization (TAI). Berdasarkan analisis deskriptif hasil belajar menulis siswa kelas IV SD Inpres Pabarung Kec. Tombolo Pao diperoleh bahwa rata-rata skor tes hasil belajar siswa pada siklus I adalah 69,83 sedangkan rata-rata skor hasil belajar siswa pada siklus II adalah 82,17 dari skor ideal 100 yang mungkin bisa dicapai. Hal ini menunjukkan bahwa secara kuantitatif terjadi peningkatan rata-rata skor tes hasil belajar menulis siswa kelas IV SD Inpres Pabarung dan daya serap terhadap materi setelah penerapan pembelajaran menulis dengan menggunakan model pembelajaran Kooperatif tipe Team Assisted Individualization (TAI).

Pada siklus II tampak bahwa hampir semua siswa mengalami peningkatan skor hasil belajar Matematika. Hal ini disebabkan antara lain pada siklus II siswa telah mampu menyelesaikan soal sesuai prosedur yang diharapkan sehingga pada umumnya siswa dapat memperoleh skor pada setiap butir soal. 
Setelah pembelajaran dengan diterapkan model pembelajaran Kooperatif tipe Team Assisted Individualization (TAI), siswa mampu berargumen antara teman yang satu dengan yang lainnya dan saling menumbuhkan rasa solidaritas .

Berdasarkan analisis deskriptif aktifitas belajar siswa diperoleh bahwa terjadi peningkatan aktivitas belajar siswa kelas IV SD Inpres Pabarung. Jika dibandingkan hasil observasi siklus I dan II, persentase rata-rata kehadiran siswa meningkat dari $88,9 \%$ menjadi $93,33 \%$. Persentase rata-rata Siswa yang mengerjakan dan mengumpulkan PR meningkat dari $50 \%$ menjadi $91,1 \%$. Persentase rata-rata Siswa yang melakukan aktivitas lain pada saat pembelajaran berlangsung mengalami penurunan dari $16,67 \%$ menjadi $10 \%$, Persentasi rata-rata siswa yang memperhatikan dan mencatat pada saat pembelajaran mengalami peningkatan dari $73,3 \%$ menjadi $83,3 \%$, persentase rata-rata siswa yang bertanya tentang materi yang belum dimengerti mengalami penurunan dari $42,2 \%$ menjadi $47,8 \%$, persentase rata-rata siswa yang mengajukan diri untuk mengerjakan soal di papan tulis mengalami peningkatan dari $63,3 \%$ menjadi $66,7 \%$, persentase rata-rata siswa yang tidak melengkapi alat yang digunakan untuk membuat media mengalami penurunan dari $7,78 \%$ menjadi $0 \%$, persentase rata-rata siswa yang bekerja sama dan berpartisipasi dalam kelompok mengalami peningkatan dari $72,2 \%$ menjadi $83,33 \%$.

Dari segi observasi terjadi peningkatan persentase aktifitas belajar siswa kelas IV SD Inpres Pabarung kehadiran siswa mengikuti proses belajar mengajar dan jumlah siswa yang mengajukan diri dan tampil menyelesaikan soal di papan tulis menunjukkan bahwa siswa memiliki perhatian yang cukup besar dalam pembelajaran menulis, khususnya dalam penerapan model pembelajaran Kooperatif tipe Team Assisted Individualization. Peningkatan jumlah siswa yang menghadapi pertanyaan guru atau teman yang mengajukan pertanyaan menunjukkan antusias aktivitas belajar siswa dalam proses pembelajaran menulis dengan penerapan model pembelajaran Kooperatif tipe Team Assisted Individualization. Peningkatan jumlah siswa yang mengajukan pertanyaan dapat di interprestasikan bahwa sebagian besar siswa merasa lebih tertarik dan termotivasi dalam mengikuti pelajaran dengan penerapan model pembelajaran Kooperatif tipe TAI, sehingga siswa lebih banyak mempertanyakan tentang apa yang dilihatnya yang memang kurang dipahami dan dimengerti. Terjadinya peningkatan hasil belajar siswa yang juga diikuti oleh perubahan aktifitas di dalam belajar.

Penulis menyadari bahwa untuk meningkatkan aktivitas dan hasil belajar siswa sangatlah tidak mudah apalagi kemampuan siswa yang berbeda-beda dalam memahami materi pelajaran menulis. Selain itu, penggunaan model pembelajaran yang sangat berpengaruh. Model pembelajaran diterapkan guru adalah salah satu faktor yang menentukan keberhasilan dalam prestasi belajar mengajar. Pemilihan model pembelajaran yang tidak tepat dapat menurunkan motivasi dan minat belajar siswa sehingga tujuan pembelajaran tidak tercapai secara optimal. Sebab tanpa motivasi (tidak mengerti apa yang akan dipelajari dan tidak memahami mengapa hal itu perlu dipelajari) kegiatan belajar mengajar sulit untuk berhasil.

\section{KESIMPULAN DAN SARAN}

\section{Kesimpulan}

Berdasarkan hasil penelitian dan uraian pembahasan di atas, dapat disimpulkan bahwa setelah melakukan 
proses pembelajaran dengan menggunakan model pembelajaran kooperatif tipe TAI, maka: 1) Penerapan pembelajaran menulis dengan menerapkan model pembelajaran kooperatif tipe Team Assisted Individualzation (TAI) pada siswa kelas IV SD Inpres Pabarung Kec. Tombolo Pao dengan skor rata-rata hasil belajar Matematika siswa pada siklus I berada pada kategori "sedang" dari skor ideal 100, sedangkan pada siklus II mengalami peningkatan dan berada pada kategori "tinggi" dengan skor ideal 100. 2) Selain hasil belajar yang meningkat, juga terjadi peningkatan pada aktivitas siswa. Aktivitas dan semangat siswa dalam belajar mengalami peningkatan dari tiap siklus.

\section{Saran}

Sehubungan dengan kesimpulan hasil penelitian di atas, maka saran yang dapat dikemukakan oleh peneliti adalah: 1) Model pembelajaran kooperatif tipe TAI dapat menjadi salah satu alternatif model pembelajaran yang dapat diterapkan pada mata pelajaran Bahasa Indonesia untuk meningkatkan hasil belajar siswa. 2) Dalam memilih model pembelajaran sebaiknya lebih berpusat kepada sistem pembelajaran kolektif sehingga dapat lebih memotivasi siswa secara sama dalam belajar pada akhirnya dapat meningkatkan hasil belajar siswa keseluruhan. 3) Bagi siswa hendaknya lebih meningkatkan cara belajarnya khususnya pada materi menulis sehingga hasil belajarnya dapat lebih meningkat.

\section{DAFTAR PUSTAKA.}

Abimanyu, Soli \& Samad, Sulaiman. (eds). 2003 Pedoman Penulisan Skirpsi.

Fakultas Imu Pendidikan

Universitas Negeri Makassar

Anas Sudijono, 2005 ; Pengantar Evaluasi Pendidikan
Arikunto, dkk. 2008. Penelitian Tindakan Kelas. Jakarta: Bumi Aksara.

Biddulp \& Osborne Teori Pembelajaran Konstruktivisme (file:///F: /teoripembelajaran-

konstrktivisme.html, diakses 4 april 2010)

Dimiyati dan Mujiono. Hasil belajar (Pengertian dan Defenisi) Indra Munawar

(file://C; Documen and Settings\Administrator\Dekstop\Hasi 1-belajar-

pengertian dan Defenisi, diakses 28 Nopember 2009)

Djamarah, S.B.2002. Psikologi Belajar. Jakarta: Rineka Cipta.

Hamalik, Oemar. 1982. Media Pendidikan. Bandung: Alumni.

Hannafin dan Peek (1998), file://D:I Media Pembelajaran dalam Pendidikan

Weblog Yudi Nugraha SR. Htm, diakses 29 Nopember 2009

Klinger, S. 1987. Survei Metode Pengajaran Dalam Ilmu Pengetahuan Alam.

Terjemahan oleh Tim Konsultan SEQIP. Nurnberg: Fakultas Den Universitas Erlangen.

Mulyo, Anton. Dkk. 1990. Kamus Besar Bahasa Indonesia. Departemen Pendidikan dan Kebudayaan, Cet. III : Penerbit Balai Pustaka

Oemar Hamalik. Hasil belajar (Pengertian dan Defenisi) Indra Munawar

(file://C; Documen and Settings\AdministratorlDekstop\Hasi l-belajar-

pengertian dan Defenisi. , diakses 28 Nopember 2009)

Ruseffendi, 1988; Pengantar kepada Membantu Guru Mengembangkan Pembelajaran

Saidihardjo, 2005; Konsep Dasar Ilmu Pengetahuan Sosial. 
Sardiman, 2001. Interaksi dan Motivasi Belajar

Slamento. 2003. Belajar dan Faktorfaktor yang mempengaruhinya. Jakarta: Rineka

Cipta.

Sudjana, N. 2002. Dasar-dasar Proses Belajar Mengajar. Bandung: Sinar Baru.

Sumaatmadja Nursid, 2001; Inovasi dan Padigma Baru dalam Pendidikan.
Suparno, 1997; Konstruktifisme dan Menyenangkan

Syah, 2000; Psikologi Belajar.

Umar, Alimin H. 2005. Statistika. Pengantar Kedalam Pemahaman Konsep dan Aplikasi Fakultas Ilmu Pendidikan UNM.

Wingkel Siuraya, 1993. Bimbingan dan Konseling di Institusi Pendidikan 